\title{
Drug Resistance in Pathogenic Micro-organisms Isolated from Oral Herbal Medicinal Products and a Survey on the Usage of Herbal Medicine in Bangladesh
}

\author{
Samia Quaiyum ${ }^{{ }^{*}}$, Helena Fortunato ${ }^{2}$, Nowshin Farjana ${ }^{3}$ and Badrun Nessa ${ }^{4}$ \\ ${ }^{1}$ Division of Applied Bioscience, Faculty of Agriculture, Hokkaido University, Sapporo, Japan \\ ${ }^{2}$ Department Natural History Sciences, Faculty of Science, Hokkaido University, Sapporo, Japan \\ ${ }^{3}$ Department of Information and Communication Technology, Bangladesh University of Professional, Mirpur, Bangladesh \\ ${ }^{4}$ Graduate School of Environmental Science, Hokkaido University, Sapporo, Japan
}

${ }^{*}$ Corresponding author: Quaiyum S, Division of Applied Bioscience, Faculty of Agriculture, Hokkaido University, Sapporo 060-0810, Japan, Tel: +81 080 9003 6898; Email: megh1710@gmail.com

Received date: September 22, 2018; Accepted date: October 16, 2018; Published date: October 22, 2018

Copyright: @2018 Quaiyum S, et al. This is an open-access article distributed under the terms of the Creative Commons Attribution License, which permits unrestricted use, distribution, and reproduction in any medium, provided the original author and source are credited.

\begin{abstract}
Objectives: The present study was conducted to assess the condition of usage of herbal medicine from a survey study and also the drug resistance of pathogenic microorganisms present in oral herbal medicines in Bangladesh popularly used for different therapeutic purposes. At the consumer level, herbal drugs could be contaminated in various ways and antibiogram testing results can also vary.
\end{abstract}

Methods: The antibacterial potential of six herbal medicines randomly selected were tested to assess their level of contamination. Minimal Inhibitory Concentration (MIC) was performed to determine the lowest concentration of each of the herbal medicine against specific microorganisms. Moreover, among the microorganisms isolated from the tested herbal medicines, Klebsiella spp. was tested for measuring the antibiotic susceptibility for different kind of antibiotics.

Results: Number of isolated pathogenic bacteria and the percentage of resistance and susceptibility of isolated pathogens are not negligible for public health.

Conclusion: Authorities need to be more careful when inspecting freely sold herbal medicines in order to avoid possible outbreaks due to contamination of those medicines.

Keywords: Pathogenic microorganisms; Drug resistance; Antibacterial; Antibiotic susceptibility; Minimal inhibitory concentration; Public health; Survey

\section{Introduction}

Natural products have long been used as sources for the formulation of useful drugs. Archaeological evidence indicates that the use of medicinal plants dates at least to the Paleolithic, approximately 60,000 years ago. There are many forms in which herbs can be administered, the most common of which is in the form of herbal teas and plant extracts [1]. Whole herb consumption is also practiced either direct or in dried form.

The World Health Organization estimates that about $80 \%$ of the populations of some Asian and African countries use herbal medicines in primary health care [2]. Over five hundred medicinal plants have so far been enlisted for which pharmacological evaluation and ethnomedicinal survey have been conducted; however, in many cases, their microbiological aspects have not been checked out $[3,4]$. Herbal medicines play an important role in healthcare being used in the treatment of ulcers, diabetes and even in cancer therapy in many countries people rely more and more on herbal drugs as the prices of synthetic medicines increases and their possible detrimental effects are better known [5]. Unfortunately, the number of reports of people experiencing negative effects caused by the use of herbal drugs has also been increasing. Among the various reasons for this, is the often poor quality of herbal medicines. We can conclude that little or no attention has been given to the quality assurance and management of herbal medicines.

Microbial presence can vary at the different stages of drug preparation, from the collecting throughout their consumption. Similarly, found contaminants can have different antimicrobial activity. Being a developing country, accessibility, cost usefulness and accurateness of medication are important for the overall public health management in Bangladesh [6]. Antimicrobial agents of natural origin can provide the means to treat infections caused by microorganisms thus saving millions of lives. On the other hand, during the last decades, microbial resistance has increased emphasizing the need for supplementary natural products as alternatives to existing therapies. The present study was conducted to assess the condition of using herbal medicine in the capital of Bangladesh, to assess the minimum inhibitory concentration of several herbal medicines against specific clinically pathogenic microorganisms and to determine the antibiotic resistance or susceptibility of pathogens isolated from herbal medicines commonly used in Bangladesh. Results can be used to 
Citation: Quaiyum S, Fortunato H, Farjana N, Nessa B (2018) Drug Resistance in Pathogenic Micro-organisms Isolated from Oral Herbal Medicinal Products and a Survey on the Usage of Herbal Medicine in Bangladesh. J Antimicrob Agents 4: 182. doi:

advise authorities concerning the quality of herbal medicinal products available in Bangladesh.

\section{Materials and Methods}

\section{Sampling and sample processing}

The experiment was performed in six categories of oral herbal drugs in liquid formulations. Manufacturing and expiration date varied between January 2013 and February 2014. Samples were randomly collected from different registered, private drug stores in Dhaka city, Bangladesh according to the standard sampling method [7]. All samples were aseptically processed followed by homogenization of 10 $\mathrm{mL}$ of each with $90 \mathrm{~mL}$ normal saline solution and dilution of up to 10-6 for the isolation and quantification of pathogenic bacteria. 100 $\mathrm{mL}$ of sterile saline solution was used as a control. Samples were then kept at $37^{\circ} \mathrm{C}$. MIC was performed for determining the in vitro antibacterial activity of tested medicines. Antibiotic susceptibility testing was performed after the results of cultivated bacterial isolates from culture plate method experiment to check the resistance against common antibiotic.

\section{Determination of microorganisms in the samples}

$0.1 \mathrm{~mL}$ of each $10^{-3}$ and $10^{-5}$, dilutions were used and spread respectively onto a MacConkey agar plate (Hi-Media Laboratories Pvt. Ltd., India) for the triplicate enumeration of total fecal coliforms (TFC), and coliforms (especially, Escherichia coli and Klebsiella spp.), respectively. After that, the plates were incubated for $24 \mathrm{hr}$ at $44.5^{\circ} \mathrm{C}$ and $37^{\circ} \mathrm{C}$ for fecal coliforms and coliforms, respectively to observe microbial growth and isolate the different organisms. Staphylococcus spp. was isolated onto Mannitol Salt Agar (Hi-Media Laboratories Pvt. Ltd., India), by adding $0.1 \mathrm{~mL}$ of each dilution and incubation at $37^{\circ} \mathrm{C}$ for $24 \mathrm{hr}$. Selenite Cysteine Broth (SCB) was used to enrich Salmonella spp and Shigella spp growth in vivo and Alkaline Peptone Water (APW), for Vibrio spp. For the enrichment, two $10 \mathrm{~mL}$ volume of each sample was transferred into $90 \mathrm{~mL}$ of SCB and into $90 \mathrm{~mL}$ of APW respectively and incubated at $37^{\circ} \mathrm{C}$ for $6 \mathrm{hr}$. After incubation, samples were diluted up to $10^{-6}$ and $0.1 \mathrm{~mL}$ of each dilution concentration were spread onto Salmonella-Shigella agar (Hi-Media Laboratories Pvt. Ltd., India) and thiosulfate citrate bile salt sucrose agar (Hi-Media Laboratories Pvt. Ltd., India) for the isolation of Salmonella spp. and Shigella spp., and Vibrio spp., respectively. The plates were incubated at $37^{\circ} \mathrm{C}$ for $48 \mathrm{hr}$ to detect typical colonies. Finally, all isolates were biochemically examined following standard procedures [8,9]. All experiments were done in triplicate.

\section{Observation of in-vitro antibacterial activity}

For this, the Minimal Inhibitory Concentration (MIC) or broth micro-dilution assay was performed to determine the lowest concentration of each tested herbal medicine capable of inhibit the viability of the tested bacteria [10]. Two-fold serial broth dilution methods were used following the recommendations of the Clinical and Laboratory Standards Institute (2006). $100 \mu \mathrm{L}$ aliquot of the overnight $(\sim 12 \mathrm{hr})$ culture of each test bacteria was added to sterile tubes containing Mueller Hinton (MH) broth [11] with the turbidity adjusted with $0.5 \mathrm{McF}$ arland standard. Seven different volumes $(32 \mu \mathrm{L}$, $64 \mu \mathrm{L}, 128 \mu \mathrm{L}, 256 \mu \mathrm{L}, 512 \mu \mathrm{L}, 1024 \mu \mathrm{L}$ and $2048 \mu \mathrm{L}$ ) of herbal medicine samples were added to make a total volume of $3 \mathrm{~mL}$. The residual or extract concentration of the herbal medicines for each of the above mentioned volumes of the aqueous samples used in the MIC assay was determined. All the tubes were incubated at $37^{\circ} \mathrm{C}$ for $24 \mathrm{hr}$. In order to know the minimum concentration $(\mathrm{mg} / \mathrm{mL})$ of each sample extract able to delay the reproduction of the tested bacteria we visually checked the lack of turbidity in essays using the McFarland standard method.

\section{Antibiotic susceptibility test (AST) of microorganisms present in the tested herbal medicines}

Antibiotic Susceptibility Test (AST) analyses the susceptibility of bacteria to antibiotics. It is usually performed by the Kirby-Bauer method [12] to find the most appropriate antibiotic for a given pathogen. In this study, the AST were done using the disc dispersion assay on Mueller-Hinton agar (MHA, Difco, Detroit, MI) and commonly used antibiotics following the standard protocol. For this assessment, commercially available laboratory grade antibiotic discs of Penicillin G, Gentamicin, Amoxicillin, Erythromycin, Ciprofloxacin, Trimethoprim sulfamethoxazole, Azithromycin and Ampicillin were aseptically placed in Mueller-Hinton agar plates previously inoculated with the bacterial suspensions obtained earlier and prescribed turbidity as compared to that of the McFarland standard of 0.5. Should be noted that the bacteria was allowed to develop prior to the antibiotic inoculation. For this experiment, Klebsiella spp. was chosen randomly among the isolated bacteria from the herbal medicine to get the preliminary idea about the resistance of herbal medicine's bacteria.

\section{Survey study}

The survey has been conducted among the university student and the results were transferred to the excel sheet to make the column chart (Figure 1).

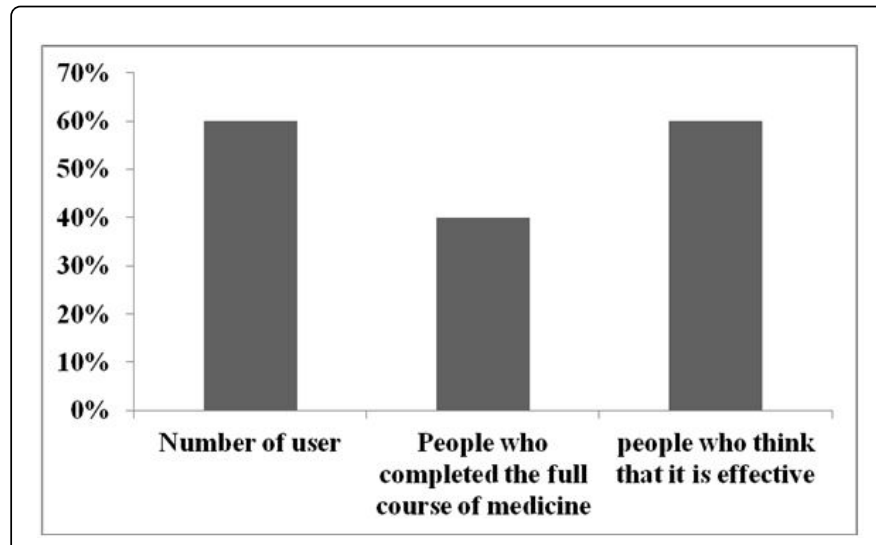

Figure 1: Survey study on the usage of herbal medicine among the university student in Bangladesh.

\section{Statstical Aanalysis}

All measurements were entered in Excel and then a single factorial analysis of variance (ANOVA) was used to test the two types of extracts (water and methanol) against specific bacterial strains. Values of $\mathrm{P}<0.05$ were taken as significant [16]. 
Citation: Quaiyum S, Fortunato H, Farjana N, Nessa B (2018) Drug Resistance in Pathogenic Micro-organisms Isolated from Oral Herbal Medicinal Products and a Survey on the Usage of Herbal Medicine in Bangladesh. J Antimicrob Agents 4: 182. doi:

Page 3 of 5

\section{Results and Discussion}

Like in Bangladesh, many countries use conventional herbal medicinal systems. Unfortunately, not all of them practice a good routine of monitoring the hygiene and the anti-bacterial potency of these drugs, which is essential to guarantee a sustainable health administration system. To our knowledge, such examination of herbal medicinal samples is not that frequent in Bangladesh as well as posing possible adverse effects upon usage of these medicines. Our survey results were conducted among the university student to know the fate of herbal medicine use in the educated and young generation. The result showed that a certain number $(60 \%)$ of student use herbal medicine and the same number also believe that it is effective. But most of them do not complete the full course of the medicine. It could be a reason to develop the drug resistance or bacterial resistance. From the microbiological study, it has found that all tested samples were found to be contaminated with bacteria $\left(10^{2}-10^{5} \mathrm{cfu} / \mathrm{mL}\right)$; although they were initially sealed (Table 1 ). The study continued afterwards once the cap was opened in order to demonstrate further microbial growth, which in turn might focus on the contamination from the environment or due to improper handling. Then the bacterial growth in all samples was also found to increase along with time up to $10^{6} \mathrm{cfu} /$ $\mathrm{mL}$. However, contamination with particular pathogenic bacterium such as, Staphylococcus aureus $\left(10^{3}-10^{5} \mathrm{cfu} / \mathrm{mL}\right)$ in all samples indicates contamination though mismanagement throughout harvesting, handing out, manufacturing, delivery or storage of the samples. All samples were found to be contaminated with Klebsiella spp. $\left(10^{2}-10^{6} \mathrm{cfu} / \mathrm{mL}\right)$, which possibly might have occurred during the harvesting process or from the farming (i.e. Manure) due to incorrect handling [13]. Sample no. 2 was contaminated with Salmonella spp. and no.4 had fecal coliforms (Table 1). All samples were contaminated with Vibrio spp $\left(10^{2}-10^{3} \mathrm{cfu} / \mathrm{mL}\right)$.

\begin{tabular}{|l|l|l|l|l|l|l|}
\hline Samples & FCC & Staphylococcus spp. & Klebsiella spp. & Salmonella spp. & Shigella spp. & Vibrio spp. \\
\hline $1(\mathrm{~N}=5)$ & 0 & $3.9 \times 10^{4}$ & $2.5 \times 10^{3}$ & 0 & 0 & $3.6 \times 10^{2}$ \\
\hline $2(\mathrm{~N}=5)$ & 0 & $4.0 \times 10^{3}$ & $1.0 \times 10^{6}$ & $1.0 \times 10^{2}$ & 0 & $4.4 \times 10^{2}$ \\
\hline $3(\mathrm{~N}=5)$ & 0 & $2.6 \times 10^{3}$ & $1.2 \times 10^{2}$ & 0 & 0 & $3.6 \times 10^{3}$ \\
\hline $4(\mathrm{~N}=5)$ & $1.0 \times 10^{3}$ & $7.0 \times 10^{3}$ & $3.0 \times 10^{5}$ & 0 & 0 & $1.0 \times 10^{2}$ \\
\hline $5(\mathrm{~N}=5)$ & 0 & $2.9 \times 10^{5}$ & $5.0 \times 10^{5}$ & 0 & 0 & $1.5 \times 10^{2}$ \\
\hline $6(\mathrm{~N}=5)$ & 0 & $1.9 \times 10^{2}$ & $4.5 \times 10^{5}$ & 0 & 0 & $2.0 \times 10^{2}$ \\
\hline
\end{tabular}

Table 1: Microbiological contamination of the studied samples $(\mathrm{cfu} / \mathrm{mL})$. The average load has been shown in the table. Total aerobic bacteria $10^{6}$ cfu/mL, [Microbial limits (World health Organization 2007), Shigella spp was completely absent].

\section{Stipulation of the in vitro anti-bacterial activity of the herbal medicine samples}

The study showed that most samples exhibited in vitro antibacterial activity against the tested bacteria used in this study. It is the first time that this is shown for these common oral herbal medicines (Table 2). Sample no. one possessed the activity against five tested bacteria successfully, sample no. two was found to be effective against two tested bacteria, while sample no. three possessed the antibacterial activity against just only one bacterium species. No antibacterial activity was found in sample no. 4-6. Additionally, the in vitro antibacterial goings-on of the samples was promote supported by observing the result of MIC (Table 2). Three samples were found to show anti-bacterial activity against E.coli, Pseudomonas spp., Bacillus spp., Salmonella spp., Staphylococcus spp., Vibrio spp. and Listeria spp. The highest MIC value was found at $40 \mathrm{mg} / \mathrm{mL}$ (Bacillus spp.) and the lowest MIC value was found at $1 \mathrm{mg} / \mathrm{mL}$ (Klebsiella spp.) (Table 2). Sample no. 1 showed MIC values between $20-40 \mathrm{mg} / \mathrm{mL}$, thus being the weakest. Sample no. 2 was the most potent against all tested microorganisms and shoed a MIC in the range of $8 \mathrm{mg} / \mathrm{mL}$ (Table 2). However, agar well diffusion and disc diffusion tests may not be the most appropriate to determine the antibacterial activity of natural compounds. The rate of diffusion of natural antimicrobials can be strongly affected by the polarity, the concentration or the molecular size of the compounds. That is why this time this experiment (MIC) was performed. No significant difference was found from the statistical analysis (Table 2).

\begin{tabular}{|l|l|l|l|l|l|l|l|l|}
\hline \multirow{2}{*}{ Sample } & \multicolumn{9}{|c|}{ Name of the microorganisms } & \multicolumn{1}{l|}{} \\
\cline { 2 - 10 } & E. coli & Klebsiella spp. & Staphylococcus spp. & Pseudomonas spp. & Salmonella spp. & Vibrio spp. & Bacillus spp. & Anova (F) \\
\hline 1 & $20 \mathrm{mg} / \mathrm{mL}$ & $38 \mathrm{mg} / \mathrm{mL}$ & $30 \mathrm{mg} / \mathrm{mL}$ & $40 \mathrm{mg} / \mathrm{mL}$ & $20 \mathrm{mg} / \mathrm{mL}$ & $20 \mathrm{mg} / \mathrm{mL}$ & $40 \mathrm{mg} / \mathrm{mL}$ & 0.10 \\
\hline 2 & $3 \mathrm{mg} / \mathrm{mL}$ & $1 \mathrm{mg} / \mathrm{mL}$ & $8 \mathrm{mg} / \mathrm{mL}$ & $8 \mathrm{mg} / \mathrm{mL}$ & $8 \mathrm{mg} / \mathrm{mL}$ & $5 \mathrm{mg} / \mathrm{mL}$ & $3 \mathrm{mg} / \mathrm{mL}$ & 0.20 \\
\hline 3 & $22 \mathrm{mg} / \mathrm{mL}$ & $22 \mathrm{mg} / \mathrm{mL}$ & $30 \mathrm{mg} / \mathrm{mL}$ & $25 \mathrm{mg} / \mathrm{mL}$ & $22 \mathrm{mg} / \mathrm{mL}$ & $22 \mathrm{mg} / \mathrm{mL}$ & $8 \mathrm{mg} / \mathrm{mL}$ & 0.15 \\
\hline
\end{tabular}

Table 2: Minimum Inhibitory Concentration (MIC) of the samples. Samples 4, 5 and 6 exhibited no MIC value, [The enduring concentrations of the herbal medicines have been provided. Among the five times separately performed experiment data, one data has been shown here.] 
Citation: Quaiyum S, Fortunato H, Farjana N, Nessa B (2018) Drug Resistance in Pathogenic Micro-organisms Isolated from Oral Herbal Medicinal Products and a Survey on the Usage of Herbal Medicine in Bangladesh. J Antimicrob Agents 4: 182. doi:

\section{Tests of the drug-resistance in pathogens isolated from the studied herbal medicines}

Nowadays, many drug-resistant bacteria are isolating from food, water and also from the synthetic drugs as well which could be alarming in the near future [14].

In this study, one of the pathogens isolated from the studied samples was used for Antibiotic susceptibility testing. Klebsiella spp. exhibited up to $69 \%$ resistance and it was found to be highly resistant to penicillin $G$ and gentamicin (Table 3). Drug-resistant pathogenic isolate from all of the samples studied may create a further danger to the overall public health remedies in the course of the application of these medicines. So our advice is to do the routine inspection of herbal medicines for the presence of drug-resistant bacteria is thus necessary.

\begin{tabular}{|l|l|l|l|l|l|l|l|}
\hline Klebsiella spp. & A & C & E & G & P & Tr & Az \\
\hline $\begin{array}{l}(\mathrm{S}-31 \% \text { (n-69\%) } \\
\text { Ro }\end{array}$ & $11 \mathrm{~mm}$ & $22 \mathrm{~mm}$ & $6 \mathrm{~mm}$ & $0 \mathrm{~mm}$ & $0 \mathrm{~mm}$ & $25 \mathrm{~mm}$ & $9 \mathrm{~mm}$ \\
\hline
\end{tabular}

Table 3: Determination of resistance or susceptibility (in $\mathrm{mm}$ ) of Klebsiella spp. to commonly used antibiotics. Data indicates the frequency of resistance or sensitivity of Klebsiella spp isolates compared with Staphylococcus spp. P=Penicillin G $(10 \mu \mathrm{g})$, $\mathrm{G}=$ Gentamicin $(10 \mu \mathrm{g}), \mathrm{A}=$ Amoxicillin $(30 \mu \mathrm{g}), \mathrm{E}=$ Erythromycin $(15$ $\mu \mathrm{g}), \mathrm{C}=$ Ciprofloxacin $(5 \mu \mathrm{g}), \mathrm{Tr}=$ Trimethoprim-sulfamethoxazole $(25$ $\mu \mathrm{g}), \mathrm{Az}=$ Azithromycin $(15 \mu \mathrm{g}), \mathrm{A}=$ Ampicillin $(10 \mu \mathrm{g}) . \mathrm{R}=$ Resistant, $\mathrm{S}=$ Sensitive.

\section{Conclusions}

In general, the development of microorganisms in the tested samples with minor anti-bacterial activity demands better formulation as well as proper handling of oral herbal medicines. The presence of bacteria in the tested herbal medicines reveals inappropriate hygiene and maintenance during manufacturing and processing phases. The growth and proliferation of pathogenic bacteria will lead to danger during the usage of these medicines. Besides, the complete absence of anti-bacterial properties in the majority of the tested samples shows their ineffectiveness against pathogenic infections. Taken together, a careful formulation of the herbal medicines, good manufacturing practices along with good and tested quality management is recommended for improved medication against diseases.

About 2,000 medicinal plants are presently included in the traditional medicine practices. Over 500 of them have so far been enlisted as growing in Bangladesh. Although a huge pharmacological evaluation and ethnomedicinal survey of medicinal plants have been conducted in the country, there is no microbiological survey of these popular medicines in spite of the wide research on microbiological assessment of pharmaceutical products [15-18]. In Bangladesh, over $80 \%$ of the rural population depends on traditional remedies for common ailments such as a cough, cold, fever, headache and dysentery. Neem (Azadirachta indica), for example, is used to treat some skin disease and in cosmetics. Turmeric is used as an anti-inflammatory, to treat digestive disorders and skin diseases, and in wound healing. Despite this, and the presence of more than 400 companies producing herbal medicines, more than $90 \%$ of the plants and products needed to meet demand are imported from India, Nepal, and Pakistan. Plants such as garlic, mint, turmeric and neem could boost Bangladesh's economy if planted on a larger scale, even if it is just in villagers' backyards. Although Bangladesh has no official policy or regulations about growing, conserving and marketing of medicinal plants, some universities and non-governmental organizations are collaborating to boost the country's production of these plants.

\section{Acknowledgement}

We are thankful to all lab members of the Microbiology department, Stamford University Bangladesh and Nowshin Farjana for conducting the survey report.

\section{Conflict of Interest}

All authors revised the manuscript and there is no conflict of interest.

\section{References}

1. Bashar S, Omar S (2011) Greco-Arab and Islamic herbal medicine: Traditional system, ethics, safety, efficacy, and regulatory issues. John Wiley \& Sons.

2. World Health Organization (2007) WHO guidelines for assessing quality of herbal medicines with reference to contaminants and residues.

3. Hemraj V, Anil J (2009) Antimicrobial activity of medicinal plants: Review. Int J Res Phar Bio Sci.

4. Rahmatullah M, Jahan R, Khatun MA, Jahan FI, Azad AK, et al. (2010) A pharmacological evaluation of medicinal plants used by folk medicinal practitioners of Station Purbo Para Village of Jamalpur Sadar Upazila in Jamalpur district, Bangladesh. Ame Eur J Sus Agri 4: 170-195.

5. Talalay P, Talalay $\mathrm{P}$ (2001) The importance of using scientific principles in the development of medicinal agents from plants. Acad Med 76: 238-247.

6. Sri AFK, Soraya RM, Agusrini M (2017) Antimicrobial lotion containing red Piper betle leaf (Piper crocatum Ruiz and Pav) ethanolic extract for topical application. Nat J of Phys Phar Phar 8: 1-9.

7. Abdur R, Md SS, Shaheda Z, Sayema K, Mamunur R (2015) A Survey of the role of community pharmacists in Dhaka city, Bangladesh. Bangla Pharm J 18: 137-141.

8. Md SR, Sharmila H (2014) Antimicrobial resistance and related issues: An overview of Bangladesh situation. Bangladesh J Pharmacol 9: 1-7.

9. Yuan R, Hou Y, Sun W, Yu J, Liu X, et al. (2017) Natural products to prevent drug resistance in cancer chemotherapy: A review. Ann N Y Acad Sci 1: 19-27.

10. American Public Health Association (1998) Standard methods for the examination of water and wastewater. (20th edn) American Public Health Association, Washington, D.C.

11. Cappuccino JG, Sherman N (1996) Microbiology-A laboratory manual. The Benjamin/Cummings Publishing Co., Menlo Park, California.

12. Alfrad EB (2007) Bensons microbiological applications. Mcgraw-Hill Book Company, New York pp: 170-175.

13. James HJ, Mary JF (2009) Antimicrobial susceptibility testing: A review of general principles and contemporary practices. Clin Infect Dis 49: 1749-1755.

14. Jorgensen JH, Turnidge JD. Mannual of clinical microbiology (11th edn).

15. Bauer AW, Kirby WM, Sherris JC, Turck M (1966) Antibiotic susceptibility testing by a standardized single disk method. Am J Clin Pathol 36: 493-496.

16. Howell DC (2002) Statistical methods for psychology. National Library of Australia, Duxbury.

17. Duraisankar M, Ravindran AD (2013) Microbial quality of herbal medicine in production unit. Int J Pharm Life Sci 4: 2775-2779.

18. Molton JS, Tambyah PA, Ang BS, Ling ML, Fisher DA (2013) The global spread of healthcare-associated multidrug-resistant bacteria: A perspective from Asia. Clin Infect Dis 56: 1310-1318. 
Citation: Quaiyum S, Fortunato H, Farjana N, Nessa B (2018) Drug Resistance in Pathogenic Micro-organisms Isolated from Oral Herbal Medicinal Products and a Survey on the Usage of Herbal Medicine in Bangladesh. J Antimicrob Agents 4: 182. doi:

10.4172/2472-1212.1000182

Page 5 of 5

19. Barbour EK, Al Sharif M, Sagherian VK, Habre AN, Talhouk RS, et al (2004) Screening of selected indigenous plants of Lebanon for antimicrobial activity. J Ethno pharm 93: 1-7.

20. Behera B, Purvia R, Yadav D, Mc S (2013) Review on anti-diabetic plants of different nighantus (Ayrvedic Materia Medica). Ayurpharm Int J Ayurveda Allied Sci 2: 92-97.
21. Chan K (2003) Some aspects of toxic contaminants in herbal medicines. Chemosphere 52: 1361-1371.

22. Cragg GM, Newman DJ (2013) Natural products: A continuing source of novel drug leads. Biochim Biophys Acta 1830: 3670-3695. 